\title{
BIO-MEDICINAL STUDIES OF SOME NEW TRIORGANOBISMUTH (V) COMPOUNDS
}

\author{
TRIPATHI D.M. ${ }^{1}$, AMRESH G. ${ }^{2}$ AND RAVI KANT1 ${ }^{*}$ \\ 1Department of Applied Chemistry, Heeralal Yadav Institute of Technology \& Management, Lucknow, UP, India. \\ ${ }^{2}$ Goel Institute of Pharmacy and Sciences, Lucknow, UP, India. \\ *Corresponding Author: Email- drravikant78@gmail.com
}

Received: April 04, 2012; Accepted: May 03, 2012

\begin{abstract}
Some new triorganobismuth (V) amide were synthesized by earlier reported method and fully characterized by their elemental and I.R. spectral analysis along with their antimicrobial activity against different pathogenic bacterial and fungal strains and in-vitro antitumor activity against human breast and mammary cancer cell line. It was found that compounds have great potential as antitumor and antimicrobial agents.
\end{abstract}

Keywords- Antimicrobial, antitumor, triorganobismuth

Citation: Tripathi D.M., Amresh G. and Ravi Kant (2012) Bio-medicinal Studies of Some New Triorganobismuth (V) Compounds. International Journal of Chemical Research, ISSN: 0975-3699 \& E-ISSN: 0975-9131, Volume 4, Issue 1, pp.-118-121.

Copyright: Copyright@2012 Tripathi D.M, et al. This is an open-access article distributed under the terms of the Creative Commons Attribution License, which permits unrestricted use, distribution, and reproduction in any medium, provided the original author and source are credited.

\section{Introduction}

There is an enormous potential for the application of metals in medicine [1] and the selection of metal ions offer the possibility for the discovery of metallodrugs with novel mechanism of action. Metal containing compounds may offer certain advantages over pure organic compound in drug therapy i.e. the metal complexes may acts as a pro-drug [2]. Bismuth compounds have attracted considerable interest owing to their biological and medicinal utility [3-5].They have been utilized from more than two centuries in the treatment of gastrointestinal disorders such as dyspepsia, diarrhea and peptic ulcer[6-9]. Bismuth salts such as colloidal bismuth sub-citrate (CBS), bismuth sub-salicylate (BSS), and ranitidine bismuth citrate $(\mathrm{RBC})$ are common agents used for Helicobacter pylori eradication therapy $[10,11]$ and therefore promoted these compounds as antimicrobials [12-20]. It is known that metals are able to generate reactive oxygen species (ROS) which easily explain the treatment of cancer [21]. In search of antiproliferative studies, a variety of organobismuth compounds have been synthesized and tested in-vitro for their antitumor activity along with their antimicrobial activity [22-27]. Despite the long history of organobismuth as bio-medicinal agents, the mechanism of action is not fully understood $[3,10,11,20]$ which is an im- portant issue for us to know that how organobismuth compound act against microorganisms and tumors. The present communication reveals the antimicrobial and antitumor activity of some fluorine containing organobismuth compounds.

\section{Experimental}

The tris(Pentafluorophenyl) bismuth (V) dichloride was synthesized by the methods reported earlier $[28,29]$. The substituted amides were recrystalized before use. The reactions were performed under inert/nitrogen atmosphere. Preparation of some representative organobismuth compounds are discussed below.

\section{Reaction of tris (Pentafluorophenyl) bismuth (V) dichloride with 5-bromoisatin}

In oxygen free nitrogen atmosphere a solution of tris (Pentafluorophenyl) bismuth (V) dichloride $(1 \mathrm{mmol})$ in methanol $(40 \mathrm{ml})$ and 5 -bromoisatin $(2 \mathrm{mmol})$ in the same solvent was stirred together in presence of triethylamine at room temperature for 5 hrs. The $\mathrm{Et}_{3} \mathrm{~N} . \mathrm{HCl}$ formed was filtered off under nitrogen atmosphere and the filtrate on concentration in vacuum gives a yellow color crystalline solid which was further recrystalized in petroleum ether $\left(40-60^{\circ} \mathrm{C}\right)$. 


\section{Reaction of tris (Pentafluorophenyl) bismuth (V) dichloride with 6-chloro-5-methoxyisatin}

In oxygen free nitrogen atmosphere a solution of tris (Pentafluorophenyl) bismuth (V) dichloride $(1 \mathrm{mmol})$ in methanol $(40 \mathrm{ml})$ and 6-chloro-5-methoxyisatin $(2 \mathrm{mmol})$ in the same solvent was stirred together in presence of triethylamine at room temperature for $5 \mathrm{hrs}$. The $\mathrm{Et}_{3} \mathrm{~N}$. $\mathrm{HCl}$ formed was filtered off under nitrogen atmosphere and the filtrate on concentration in vacuum gives an off-white color crystalline solid which was further recrystalized in pet. ether $\left(40-60^{\circ} \mathrm{C}\right)$.

\section{Reaction of tris (Pentafluorophenyl) bismuth (V) dichloride with 6-methoxy-5-bromoisatin}

In oxygen free nitrogen atmosphere a solution of tris (Pentafluorophenyl) bismuth $(\mathrm{V})$ dichloride $(1 \mathrm{mmol})$ in methanol $(40 \mathrm{ml})$ and 6-methoxy-5-bromoisatin $(2 \mathrm{mmol})$ in the same solvent was stirred together in presence of triethylamine at room temperature for $5 \mathrm{hrs}$. The $\mathrm{Et}_{3} \mathrm{~N}$. $\mathrm{HCl}$ formed was filtered off under nitrogen atmosphere and the filtrate on concentration in vacuum afforded yellow color crystalline solid which was further recrystalized in pet. ether $\left(40-60^{\circ} \mathrm{C}\right)$.

\section{Reaction of tris (Pentafluorophenyl) bismuth (V) dichloride with 7-chloroisatin}

In oxygen free nitrogen atmosphere a solution of tris (Pentafluorophenyl) bismuth (V) dichloride $(1 \mathrm{mmol})$ in methanol $(40 \mathrm{ml})$ and 7 -chloroisatin $(2 \mathrm{mmol})$ in the same solvent was stirred together in presence of triethylamine at room temperature for 5 hrs. The $\mathrm{Et}_{3} \mathrm{~N} . \mathrm{HCl}$ formed was filtered off under nitrogen atmosphere and the filtrate on concentration in vacuum afforded offwhite color crystalline solid which was further recrystalized in pet. ether $\left(40-60^{\circ} \mathrm{C}\right)$.

\section{Antibacterial Activity}

Antibacterial activity of the synthesized compound was carried out by disc diffusion method [30] using ampicilin as standard. The filter paper (Whatman No.1) sterile disc of $5 \mathrm{~mm}$ diameter, impregnated with the test compounds $(10 \mathrm{mg} / \mathrm{ml}$ of ethanol) along with standard were placed on the nutrient agar plate at $37^{\circ} \mathrm{C}$ for $24 \mathrm{hrs}$ in BOD incubator. The inhibition zone around the dried impregnated disc was measured after $24 \mathrm{hrs}$.

\section{Antifungal Activity}

The antifungal activity of the compound was tested by agar plate diffusion method [31], using ampicilin as standard. Four concentrations of the test compounds viz., 10, 20, 50 and $100 \mathrm{mg} / \mathrm{ml}$ were prepared and tested against two pathogenic fungal strains, Aspergillus flavus and Aspergillus niger. The $1 \mathrm{ml}$ of each compound was poured into a petri dish containing $20-25 \mathrm{ml}$ of molten potato dextrose-agar medium. As the medium solidify, petri dishes were incubated at $37^{\circ} \mathrm{C}$ for $96 \mathrm{hrs}$ in BOD incubator. After $96 \mathrm{hrs}$ the colony diameter was measured and $\%$ inhibition was calculated using standard method (32).

\section{Antitumor Activity}

The in-vitro antitumor activity of these compounds was carried out by MTT-method [33]. This method was performed to estimate the effect of compounds on the growth of cell. The human breast ade- nocarcinoma (MCF-7) and mammary cancer (EVSA-7) cell lines were used for this purpose. The principle behind this assay depends upon the reduction of tetrazoleum salt. The yellow colored tetrazoleum MTT [3-(4, 5-dimethylthiazolyl-2)-2,5-diphenyl tetrazoleum bromide] was reduced partially by metabolically active cells by the action of dehydrogenase enzyme to generate NADH and NADPH as reducing equivalents. The resulting intracellular purple color zone was solubilized and quantified by spectrophotometer. The MTT was first dissolved in Phosphate buffer saline at a concentration of $5 \mathrm{mg} / \mathrm{ml}$. The MTT solution $(50 \mathrm{ml})$ was added to each well of 96 well culture plate containing $100 \mathrm{ml}$ of culture medium and incubates at $37 \mathrm{C}$ for $4 \mathrm{hrs}$. The medium was then removed carefully without disturbing the crystals of purple colored zone then $50 \mathrm{ml}$ of DMSO was added to each well and mixed thoroughly to dissolve the crystals of the zone. The plate was then read on a micro ELISA plate reader at a wavelength of $570 \mathrm{~nm}$ to fine out the optical density and cell count value.

\section{Results and Discussion}

The tris(Pentafluorophenyl) bismuth(V) amides can be easily obtained by using metathetical reaction where a respective isatin reacted will tris(Pentafluorophenyl) bismuth(V) dichloride in an appropriate ratio in presence of triethylamine which behaves as hydrogen chloride acceptor.

$\mathrm{R}_{3} \mathrm{BiCl}_{2}+2 \mathrm{HL} \stackrel{\mathrm{Et}_{3} \mathrm{~N}}{\longrightarrow} \mathrm{R}_{3} \mathrm{BiL}_{2}+2 \mathrm{Et}_{3} \mathrm{~N} . \mathrm{HCl}$

$\mathrm{R}=\mathrm{C}_{6} \mathrm{~F}_{5}, \mathrm{HL}=\mathrm{HNR}_{2}=6$-Chloro-5Methoxy, 6-Methoxy-5 Bromo, 7Chloro, 6-Bromo-5Methoxy, 5-bromo and 5 methoxy isatin.

The reactions were performed in room temperature and under nitrogen atmosphere. The organobismuth compounds which were obtained have sharp melting point and stable towards air and moisture. These compounds were also characterized on the basis of their elemental analysis, I.R. spectra, antibacterial, antifungal and antitumor activity in human breast and mammary tumor cell line in-vitro.

\section{Infrared Spectra}

The I.R. spectra of these compounds show almost similar absorption bands due to presence of Pentafluorophenyl group. The position and pattern of these absorption bands do not differ much from the I.R. data of tris (Pentafluorophenyl) bismuth (V) halides. A remarkable features in the I.R. spectra of all these compound is the absence of $\mathrm{v}_{\mathrm{sym}}(\mathrm{Bi}-\mathrm{C})$ absorption corresponding to't' mode which should be located in the region of $250-300 \mathrm{~cm}^{-1}$. The absorption frequencies having diagnostic values are listed in table.

\footnotetext{
Antibacterial Activity

The organobismuth compounds were tested for antibacterial activity against three bacterial strains Pseudomonas aeruginosa, Staphylococcus aureus and Klebsiela pneumoniae using $10 \mathrm{mg} / \mathrm{ml}$ concentration of test compound. All the compounds show moderate to higher activity against the bacterial strains. The efficacy of these compounds against three bacterial strains was moderate. It was found that compounds containing pentafluorophenyl ring are more effective because of their water and lipid solubility. The fluorine-containing compounds may generally form complexes with
} 
metaloenzymes, particularly those which responsible in basic physiology such as cytochrome oxidase. These compounds may react with peptidoglycan layer of bacterial cell wall and damage it by penetrating in such a manner that the two aromatic rings gets entered inside the cell by puncturing it followed by death of bacterial cell. Some times these compounds in low concentration may cause bacteriostatic condition by slow down the growth of bacteria.

\section{Antifungal Activity}

The antifungal activity of these compounds were tested against Aspergillus flavus and Aspergillus niger using concentrations 10, 20,50 and $100 \mathrm{mg} / \mathrm{ml}$. Activity of the compound was found variable at lower concentration but at higher concentration compounds show high activity against fungal strains. Presence of nitrogen and pentafluorophenyl ring along with bismuth may responsible for fungal activity. Compounds generally damage the fungal strains by puncturing the cell wall similarly as in case of bacteria. It is well know that the Lewis acidic nature of bismuth may also affect the fungal activity. Water and lipid solubility also increases the activity due to presence of fluorine.

\section{Antitumor Activity}

Antitumor activity of these compounds was studied against the human breast adenocarcinoma (MCF-7) and mammary cancer (EVSA-7) cell lines. The compounds show moderate to higher activity against tumor cell lines. It was found that the slight variation in their activity is due to presence of different amides as ligands along with presence of fluorine on main moiety of the compound. The compound generally interacts with the receptor site of multienzyme complex responsible for the cytostatic and cytotoxic conditions for a cell. It may be noted that the organobismuth compound generally binds with nitrogen 7 positions of the purine bases in DNA molecule, where they reacted with labile hydrogen and form complex with DNA strands affecting replication and transcription of DNA molecule and stop the cell division along with protein synthesis.

Table-2 Antibacterial Activity

\begin{tabular}{lllll}
$\begin{array}{l}\text { S. Compounds } \\
\text { No. }\end{array}$ & $\begin{array}{l}\text { Pseudomo- } \\
\text { nas aeru- } \\
\text { ginosa }\end{array}$ & $\begin{array}{l}\text { Staphylococ- } \\
\text { cus aureus }\end{array}$ & $\begin{array}{l}\text { Klebsiela } \\
\text { pneumoniae }\end{array}$ \\
\hline 1. & $\mathrm{C}_{34} \mathrm{H}_{6} \mathrm{~F}_{15} \mathrm{~N}_{2} \mathrm{O}_{4} \mathrm{Br}_{2} \mathrm{Bi}$ & $11.00 \pm 0.57$ & $8.10 \pm 0.16$ & $12.00 \pm 1.15$ \\
2 & $\mathrm{C}_{36} \mathrm{H}_{10} \mathrm{~F}_{15} \mathrm{Cl}_{2} \mathrm{~N}_{2} \mathrm{O}_{6} \mathrm{Bi}$ & $10.94 \pm 0.48$ & $8.04 \pm 0.10$ & $11.88 \pm 0.70$ \\
3. & $\mathrm{C}_{36} \mathrm{H}_{10} \mathrm{~F}_{15} \mathrm{~N}_{2} \mathrm{O}_{6} \mathrm{Br}_{2} \mathrm{Bi}$ & $11.33 \pm 0.66$ & $11.00 \pm 0.57$ & $8.58 \pm 0.29$ \\
4. & $\mathrm{C}_{34} \mathrm{H}_{6} \mathrm{~F}_{15} \mathrm{~N}_{2} \mathrm{O}_{4} \mathrm{Cl}_{2} \mathrm{Bi}$ & $11.24 \pm 0.60$ & $8.70 \pm 0.26$ & $12.06 \pm 0.77$ \\
5 & $\mathrm{C}_{36} \mathrm{H}_{10} \mathrm{~F}_{15} \mathrm{~N}_{2} \mathrm{O}_{6} \mathrm{Br}_{2} \mathrm{Bi}$ & $11.42 \pm 0.68$ & $11.12 \pm 0.0 .62$ & $8.72 \pm 0.32$ \\
6 & $\mathrm{C}_{36} \mathrm{H}_{12} \mathrm{~F}_{15} \mathrm{~N}_{2} \mathrm{O}_{6} \mathrm{Bi}$ & $11.33 \pm 0.66$ & $11.00 \pm 0.57$ & $8.54 \pm 0.22$ \\
7 & $\mathrm{C}_{34} \mathrm{H}_{6} \mathrm{~F}_{15} \mathrm{~N}_{2} \mathrm{O}_{4} \mathrm{Cl}_{2} \mathrm{Bi}$ & $12.06 \pm 0.77$ & $10.94 \pm 0.48$ & $11.00 \pm 0.57$ \\
8 & Ampicilin (standard) & $18.0 \pm 0.21$ & $12.66 \pm 0.50$ & $16.26 \pm 0.30$ \\
\hline
\end{tabular}

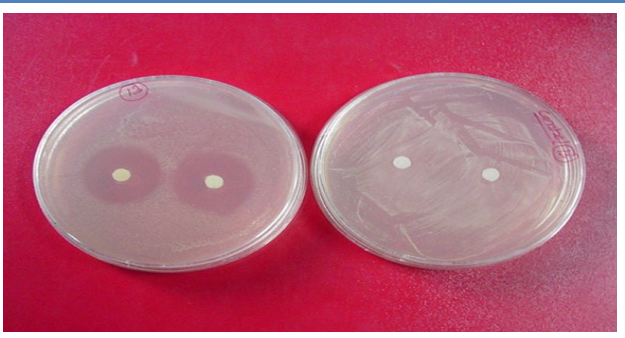

[Antibacterial Activity of organobismuth compound $\mathrm{C}_{34} \mathrm{H}_{6} \mathrm{~F}_{15} \mathrm{~N}_{2} \mathrm{O}_{4} \mathrm{Cl}_{2} \mathrm{Bi}$ against Pseudomonas aeruginosa]
Table 3- Antifungal Activity

\begin{tabular}{|c|c|c|c|c|c|c|}
\hline $\begin{array}{l}\text { S. } \\
\text { No. }\end{array}$ & Compounds & $\begin{array}{l}\text { Con. } \\
\mathrm{mgl} \\
\mathrm{ml}\end{array}$ & $\begin{array}{l}\text { Asper- } \\
\text { gillus } \\
\text { flavus } \\
\text { (dia.m } \\
\text { m) }\end{array}$ & $\begin{array}{l}\% \\
\text { Inhi- } \\
\text { bitio } \\
n\end{array}$ & $\begin{array}{l}\text { Asper- } \\
\text { gillus } \\
\text { niger } \\
\text { (dia.m } \\
\text { m) }\end{array}$ & $\begin{array}{l}\% \\
\text { Inhi- } \\
\text { bition }\end{array}$ \\
\hline \multirow[t]{4}{*}{1.} & \multirow[t]{4}{*}{$\mathrm{C}_{34} \mathrm{H}_{6} \mathrm{~F}_{15} \mathrm{~N}_{2} \mathrm{O}_{4} \mathrm{Br}_{2} \mathrm{Bi}$} & 10 & 1.4 & 53.3 & 1.0 & 50.0 \\
\hline & & 20 & 1.0 & 66.6 & 0.8 & 60.0 \\
\hline & & 50 & 0.7 & 76.6 & 0.5 & 75.0 \\
\hline & & 100 & 0.4 & 86.7 & 0.2 & 90.0 \\
\hline \multirow[t]{4}{*}{2.} & \multirow[t]{4}{*}{$\mathrm{C}_{36} \mathrm{H}_{10} \mathrm{~F}_{15} \mathrm{Cl}_{2} \mathrm{~N}_{2} \mathrm{O}_{6} \mathrm{Bi}$} & 10 & 1.2 & 60.0 & 1.4 & 30.0 \\
\hline & & 20 & 1.0 & 66.6 & 1.0 & 50.0 \\
\hline & & 50 & 0.8 & 73.3 & 0.8 & 60.0 \\
\hline & & 100 & 0.5 & 83.3 & 0.4 & 80.0 \\
\hline \multirow[t]{4}{*}{3.} & \multirow[t]{4}{*}{$\mathrm{C}_{36} \mathrm{H}_{10} \mathrm{~F}_{15} \mathrm{~N}_{2} \mathrm{O}_{6} \mathrm{Br}_{2} \mathrm{Bi}$} & 10 & 0.8 & 73.3 & 1.5 & 25.0 \\
\hline & & 20 & 1.2 & 60.0 & 1.2 & 40.0 \\
\hline & & 50 & 1.0 & 66.6 & 0.8 & 60.0 \\
\hline & & 100 & 0.8 & 73.3 & 0.5 & 75.0 \\
\hline \multirow[t]{4}{*}{4.} & \multirow[t]{4}{*}{$\mathrm{C}_{34} \mathrm{H}_{6} \mathrm{~F}_{15} \mathrm{~N}_{2} \mathrm{O}_{4} \mathrm{Cl}_{2} \mathrm{Bi}$} & 10 & 1.2 & 60.0 & 1.4 & 30.0 \\
\hline & & 20 & 1.0 & 66.6 & 1.2 & 40.0 \\
\hline & & 50 & 0.6 & 80.0 & 0.5 & 75.0 \\
\hline & & 100 & 0.4 & 86.7 & 0.2 & 90.0 \\
\hline \multirow[t]{4}{*}{5.} & \multirow[t]{4}{*}{$\mathrm{C}_{36} \mathrm{H}_{10} \mathrm{~F}_{15} \mathrm{~N}_{2} \mathrm{O}_{6} \mathrm{Br}_{2} \mathrm{Bi}$} & 10 & 1.2 & 60.0 & 1.0 & 50.0 \\
\hline & & 20 & 0.7 & 76.6 & 1.0 & 50.0 \\
\hline & & 50 & 0.5 & 83.3 & 0.5 & 75.0 \\
\hline & & 100 & 0.1 & 96.7 & 0.2 & 90.0 \\
\hline \multirow[t]{4}{*}{6.} & \multirow[t]{4}{*}{$\mathrm{C}_{36} \mathrm{H}_{12} \mathrm{~F}_{15} \mathrm{~N}_{2} \mathrm{O}_{6} \mathrm{Bi}$} & 10 & 1.4 & 53.3 & 1.0 & 50.0 \\
\hline & & 20 & 0.7 & 76.6 & 1.0 & 50.0 \\
\hline & & 50 & 0.6 & 80.0 & 0.5 & 75.0 \\
\hline & & 100 & 0.4 & 86.7 & 0.2 & 90.0 \\
\hline \multirow[t]{4}{*}{7.} & \multirow[t]{4}{*}{$\mathrm{C}_{34} \mathrm{H}_{6} \mathrm{~F}_{15} \mathrm{~N}_{2} \mathrm{O}_{4} \mathrm{Cl}_{2} \mathrm{Bi}$} & 10 & 1.2 & 60.0 & 1.4 & 30.0 \\
\hline & & 20 & 1.0 & 66.6 & 0.8 & 60.0 \\
\hline & & 50 & 0.5 & 83.3 & 0.5 & 75.0 \\
\hline & & 100 & 0.1 & 96.7 & 0.2 & 90.0 \\
\hline 8. & Control & & 3.0 & - & 2.0 & - \\
\hline
\end{tabular}

Table 4- Antitumor Activity

\begin{tabular}{|c|c|c|c|c|c|}
\hline $\begin{array}{l}\text { S. } \\
\text { No. }\end{array}$ & Compounds & $\begin{array}{l}\text { Cell No. X } \\
10^{4} \text { (MCF-7) }\end{array}$ & $\begin{array}{l}\text { Activ- } \\
\text { ity }\end{array}$ & $\begin{array}{l}\text { Cell No. } x \\
10^{4} \\
\text { (EVSA-7) }\end{array}$ & $\begin{array}{l}\text { Ac- } \\
\text { tivit } \\
y\end{array}$ \\
\hline 1. & $\mathrm{C}_{34} \mathrm{H}_{6} \mathrm{~F}_{15} \mathrm{~N}_{2} \mathrm{O}_{4} \mathrm{Cl}_{2} \mathrm{Bi}$ & $9.69 \pm 0.92$ & + & $10.68 \pm 1.08$ & - \\
\hline 2. & $\mathrm{C}_{34} \mathrm{H}_{6} \mathrm{~F}_{15} \mathrm{~N}_{2} \mathrm{O}_{4} \mathrm{Cl}_{2} \mathrm{Bi}$ & $9.66 \pm 0.90$ & + & $10.62 \pm 1.06$ & - \\
\hline 3. & $\mathrm{C}_{34} \mathrm{H}_{6} \mathrm{~F}_{15} \mathrm{~N}_{2} \mathrm{O}_{4} \mathrm{Cl}_{2} \mathrm{Bi}$ & $8.28 \pm 0.46$ & + & $9.69 \pm 0.92$ & + \\
\hline 4. & $\mathrm{C}_{34} \mathrm{H}_{6} \mathrm{~F}_{15} \mathrm{~N}_{2} \mathrm{O}_{4} \mathrm{Cl}_{2} \mathrm{Bi}$ & $8.22 \pm 0.42$ & + & $9.68 \pm 0.88$ & + \\
\hline 5. & $\mathrm{C}_{34} \mathrm{H}_{6} \mathrm{~F}_{15} \mathrm{~N}_{2} \mathrm{O}_{4} \mathrm{Cl}_{2} \mathrm{Bi}$ & $9.62 \pm 0.52$ & + & $9.62 \pm 0.90$ & + \\
\hline 6. & $\mathrm{C}_{34} \mathrm{H}_{6} \mathrm{~F}_{15} \mathrm{~N}_{2} \mathrm{O}_{4} \mathrm{Cl}_{2} \mathrm{Bi}$ & $9.67 \pm 0.54$ & + & $9.69 \pm 0.92$ & + \\
\hline 7. & $\mathrm{C}_{34} \mathrm{H}_{6} \mathrm{~F}_{15} \mathrm{~N}_{2} \mathrm{O}_{4} \mathrm{Cl}_{2} \mathrm{Bi}$ & $9.69 \pm 0.92$ & + & $9.66 \pm 0.90$ & + \\
\hline 8. & Negative Control & $10.21 \pm 1.01$ & - & $10.23 \pm 1.03$ & - \\
\hline 9. & Positive Control & $40.26 \pm 3.23$ & - & $42.24 \pm 4.22$ & - \\
\hline
\end{tabular}

\section{References}

[1] Guo Z. and Sadler P.J. (2000) Adv. Inorg. Chem., 49, 183.

[2] Clarke M.J., Zhu F. and Frasca D.R. (1999) Chem. Rev, 99, 2511.

[3] Sadler P.J., Li H. and Sun H. (1999) Coord. Chem. Rev., 185186, 689-709.

[4] Sun H., Li H. and Sadler P.J. (1997) Chem. Ber. /Recucil, 130, 669-681.

[5] Briand G.G. and Burford N. (1999) Chem. Rev., 99, 26012657.

[6] Rambert J.R. (1991) Rev.Infect. Dis., 13(8), S691-S695.

[7] Gorbich S.L. (1990) Gastroenterology, 99, 863-875.

[8] Marshall B.J. (1991) Am.J. Gastroenterol, 86, 16-25.

[9] Baxter G.F. (1992) Chem. Brit.,445-44

[10]Rambert J.R. and Midolo P. (1997) Aliment. Pharmacol. Ther., 11(1), 27-33. 
[11]Chiba N. (2000) Can.J. Gastroenterol.14, 885-889.

[12]Dittes U., Vogel E. and Keppler B.K. (1997) Coord. Chem. Rev.163, 345-364.

[13]Dahlgren A., Glogard C., Gammelsaether M., Aaseu A.J., Klaveness J., Berdal B.P. and Bergan T. (1999) Scand. J. Gastroenterol.135-137.

[14]Herrmann W.A., Hardwick E. and Pajdla L. (1991) Inorg. Chem., 30, 2579-2581.

[15]Asato E., Kamamuta K., Akamine Y., Fukami T., Nakuda R., Mikuriya M., Deguchi S. and Yokoto Y. (1997) Bull. Chem. Soc. Jpn., 70, 639-648.

[16]Turel I., Golic L., Bukovic P. and Gubina M. (1998) J. Inorg. Biochem., 71, 53-60.

[17]Dominico P., Salo R.J., Novick S.G., Schoch P.E., Horn K.V. and Cunha B.A. (1997) Antimicrob. Agents Chemother, 41, 1697-1703.

[18]Mahony D.E., Morison S.L., Bryden L., Faulkner G., Hoffmann P.S., Agoes L., Briand G.G., Burford N. and Maguire H. (1999) Antimicrob. Agents. Chemother, 43, 582-58.

[19]Turel I., Leban I. and Bukovec N. (1997) J. Inorg. Biochem., 66, 241-245.

[20]Stratton C.W., Warner R.R., Coudron P.E. and Lilly N.A. (1999) Antimicrob. Agents. Chemother, 43, 659-666.

[21]Smith K.A., Deacon G.B., Jackson W.R., Tiekink E.R.T.; Rainone S. and Webster L.K.(1998) Metal-based Drugs, 5, 295-
304.

[22]Murafugi T., Miyoshi Y., Ishibashi M., Mustafizur Rahman A.F.M., Sugihara Y., Miyakawa I. and Uno H. (2004) J. Inorg. Biochem., 98, 547-552.

[23]Tyagi S., Singh N., Singh S.M. and Singh U.P. (2004) Synth. React. Inorg. Met.-Org. Chem., 34, 573-591.

[24]Tie kink E.R.T. (2002) Critical Review in Oncol/Haematol, 42, 217-224.

[25]Socaciu C., Bara A., Silvestru C. and Haiduc I. (1991) In-vivo, $5,425-428$

[26]Socaciu C., Pasca I., Silvestru C., Bara A. and Haiduc I. (1994) Metal Based Drugs, 1, 291-297.

[27]Ying T.W., Singh L.C. and Tie kink E.R.T. (2002) Critical Review in Oncol/Haematol, 42, 225-231.

[28]Kant R., Singhal K., Shukla S.K., Chandrashekar K., Saxena A.K., Ranjan A. and Raj P. (2008) Phosphorus, Sulfur and Silicon, 183,2029-2039.

[29]Kant R. Amresh G., Chandrashekar K. and Anil.K.K.S. (2008) Phosphorus, Sulfur and Silicon, 183,1410-1419.

[30]Verma R.S. and Imam S.A.(1973) Ind. J. Microbial,13,45.

[31]Horshfall J.G. (1945) Bot. Rev., 5, 357.

[32]Giri S. and Khare R.K. (1976) J. Antibacterial Antifungal Agent, 4(11), 11.

[33]Mosmann T. (1983) J. Immunol. Methods, 65, 55.

Table 1- Physicochemical and Spectral Analysis of Organobismuth (V) compounds

\begin{tabular}{|c|c|c|c|c|c|c|c|c|c|c|c|}
\hline S.N. & Compounds & Formula & $\begin{array}{l}\text { Formula } \\
\text { Weight }\end{array}$ & $\begin{array}{l}\text { TI.P. } \\
\left({ }^{\circ} \mathrm{C}\right)\end{array}$ & $\begin{array}{l}\text { Yield } \\
(9 / 6)\end{array}$ & Eleme & ital $A n$ & sis (\%) & & $\left.\mathrm{cm}^{-1}\right) \mathrm{Ana}$ & \\
\hline & $\begin{array}{l}\left(\mathrm{C}_{6} \mathrm{~F}_{5}\right)_{3} \mathrm{Bi}\left(\mathrm{NR}_{2}\right)_{2} \\
-\mathrm{NR}_{2}=\end{array}$ & & & & & C & $\mathrm{H}$ & $\mathrm{N}$ & asym(CO) & sym $(\mathrm{CO})$ & $\mathrm{Bi}-\mathrm{C}$ \\
\hline 1 & "(r-Bromoisafn] & $\mathrm{C}_{34} \mathrm{~F}_{15} \mathrm{H}_{6} \mathrm{~N}_{2} \mathrm{O}_{4} \mathrm{Br}_{2} \mathrm{Bi}$ & 1160 & 156 & 75 & 35.17 & 0.51 & 2.41 & 1738 & 1312 & 454 \\
\hline 2 & [0-chloro-5-metoxyisatn] & $\mathrm{C}_{30} \mathrm{~F}_{15} \mathrm{H}_{10} \mathrm{~N}_{2} \mathrm{O}_{6} \mathrm{Cl}_{2} \mathrm{Bi}$ & 1131 & 180 & 70 & 38.19 & 0.88 & 2.47 & 1728 & 1322 & 462 \\
\hline 3 & {$[0$-methoxy-5-bromoisain] } & $\mathrm{C}_{30} \mathrm{~F}_{15} \mathrm{H}_{10} \mathrm{~N}_{2} \mathrm{O}_{6} \mathrm{Br}_{2} \mathrm{Bi}$ & 1228 & 192 & 75 & 35.17 & 0.81 & 2.28 & 1740 & 1316 & 448 \\
\hline 4 & $\underbrace{\infty}_{a} \underbrace{\infty}_{[-C h l o r o i s a i n]}$ & $\mathrm{C}_{34} \mathrm{~F}_{15} \mathrm{H}_{6} \mathrm{~N}_{2} \mathrm{O}_{4} \mathrm{Cl}_{2} \mathrm{Bi}$ & 1071 & 144 & 65 & 38.09 & 0.56 & 2.61 & 1730 & 1316 & 448 \\
\hline 5 & [6-Bromo-5-methoxyisafn] & $\mathrm{C}_{30} \mathrm{~F}_{15} \mathrm{H}_{10} \mathrm{~N}_{2} \mathrm{O}_{6} \mathrm{Br}_{2} \mathrm{Bi}$ & 1220 & 170 & 75 & 35.40 & 0.81 & 2.29 & 1726 & 1310 & 452 \\
\hline 6 & [5-methoxyisafn] & $\mathrm{C}_{30} \mathrm{~F}_{15} \mathrm{H}_{12} \mathrm{~N}_{2} \mathrm{O}_{6} \mathrm{Bi}$ & 1062 & 182 & 70 & 40.67 & 1.12 & 2.63 & 1712 & 1314 & 460 \\
\hline 7 & [5-chlonoisain] & $\mathrm{C}_{34} \mathrm{~F}_{15} \mathrm{H}_{6} \mathrm{~N}_{2} \mathrm{O}_{4} \mathrm{Cl}_{2} \mathrm{Bi}$ & 1071 & 174 & 70 & 38.09 & 0.56 & 2.61 & 1740 & 1324 & 458 \\
\hline
\end{tabular}

